\title{
$\cos f-830702-20$
}

THREE.DIMENSIONAL FINITE.ELEMENT ANALYSIS OF THE CELLULAR CONVECTION PHENOMENA IN THE CLINCH RIVER BREEDER REACTOR PLANT PROTOTYPE PUMP

\author{
A. H. Silver. Sentior Project Engincer dund J. Y. Lee. Project Enginter \\ Energy Sysiens Develupmenc Center \\ Byrun Jalikion Pump Division. Gurg. byurner Corporation \\ Curson. Culifornia
}

CONF $-830702--20$

DE83 015538

\section{ABSTRACT}

Cellular convection was studied rigorously during the development of the clinch River Breeder Peactor Plant (CRBRP) Program Pumps. The non-summetrical eifects of Eellular convection on thermal stresses, thermal distortions, and pump/foundation interjace temperatures were important considerations.

This paper presents the derelocment of $a$ three-dimensional Einite-elentent hedt =ansfer model which accounts for the celiular convection phenomena. A buoyancy driven ceilular convection flow pattern is introduced in the annulus region between the upuer inner structure and the pump tank.

Steady-state thermal data were obtainea for several test conditions for argon gas pressures up to $93 \mathrm{psig}(741 \mathrm{kPz})$ and sodium operating temperatures to $1000^{\circ} \mathrm{F}(811 \mathrm{k})$. Test temperature distributions on the pump tank and inner structure were correlated with numerical results and excellent agreement was obtained.

\section{NOMENCLATURE}

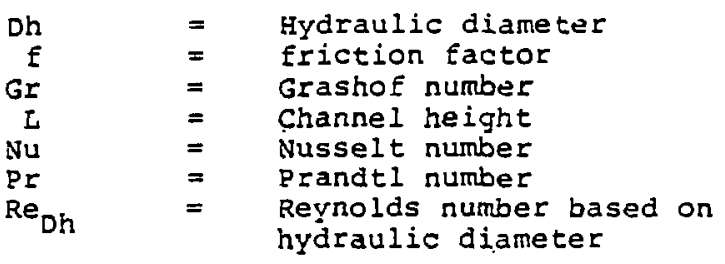

\section{INTRODUCTION}

Criteria for the onset of fluid cellulas convection in a simple annulus have been established by Edwards (1). The crituria are based on well defined thermal boundary conditions such as uniform temperatures at both top NOTHEE

PORTIONS OF THIS REPORT ARE ILLEIBLE.

It has been reproduced from the best avahable oepy to permit the broadest possibje arallability. and bottom surfaces and a single wall conduction parameter. However, the conditions encountered in the Clinch River Breeder Reactor Pump are not close to the above ideal cunditions due to the complex configuration ani large temperature variation. Therefore, an sccurate prediction of the possibility of cellular convection based on the Edwards criteria was not possible.

During operating tests conducted on the Prototype pump, a strong convection cell pair was encountered at high operating pressures. This had an adverse influence on the temperature distributions in the pump. To verify that this temperature distribution was, in sact, caused by an internal gas cell, an analytical correlation with test results was persormed. A combined thermal analysis including convection, conduction and radiation on the upper pump structure in the presence of cellular convection was attempted using a finite element thermal computer code ANSYS (2).

\section{DESCRIPTION OF THE UPPER PUMP STRUCTURE}

A cross sectional view of the upper pump structure is shown in Figure 1 . It consists of a radiation/thermal shield, a pump tank, and a pump tank flange. The radiation/thermal shield is a cylinder of 92.5 inch $(234.9 \mathrm{~cm})$ outside diameter and 60 inch $(152.4 \mathrm{~cm})$ height Eilled uith steel shot whose conductivity is about $1 / 30$ the conductivity of stainless steel. The pump tank is a 93 in. (236.2 cm) I.D. cylinder whose outside is insulated. The pump tank flange is bolted to the support structure and surrounded by ambient air. The annulus between the radiation/thermal shield (upoer inner structure) and the pump tank is filied with argon cover gas which separates the sodium from the ambient air. The innermost part of the inner structure is a pump shate which is not significant in the thermal 
analysis. Significant dimensions of thermal

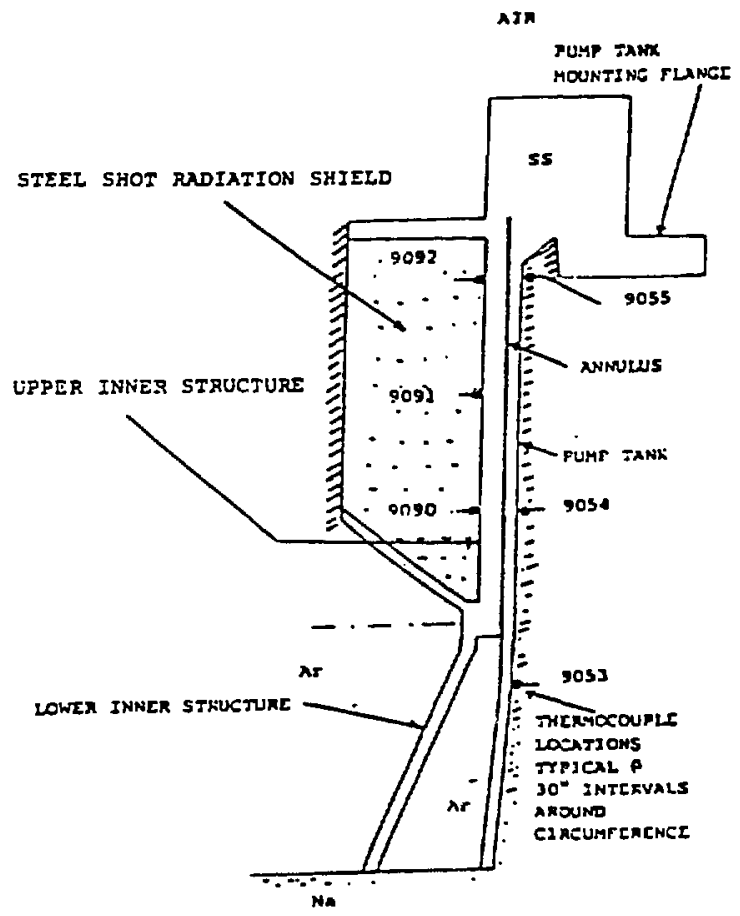

FIGURE 1. PUMP CROSS SECTIONS SHOWING THERMOCOUPLE LOCATIONS interest are listed in rable 1.

low pressure convection correlation, a four cell mode is used by reducing the circumferential dimensions of the elements in half.

2. The flow pattern in cells consists of three independent channel flows whose wetted area is the same as that of the annulus surface area. The flow areas of the hot and cold legs of the cells are approximately equal. The center column of the loop is considered stagnant. There is convection beiween the stagnant argon and surrounding solid surfaces.

The turning center of each loop is located at the middle level of the annulus.

3. Flow in the annulus is driven by imaginary pumps whose pump head is determined by the difference in the static head of the hot and cold leg.

4. The flow impedance of the loop is determined from the laminar friction factor, $f=96 /$ Re , and the pressure drop coefficiele of $3.0\left(180^{\circ}\right.$ turn and exit and entrance losses). The latter has little effect on the total flow impedance.

5. The heat transfer coefficient in the channel is obtained from (3).

$$
\mathrm{Nu}=7.54+0.0234 \frac{\mathrm{Re}_{\mathrm{Dh}} \mathrm{Pr}}{\mathrm{L} / \mathrm{Dh}}
$$

It is noted that the outermost loop has the greatest influence in determining the resultant temperature field.

\section{FINITE ELEMENT THERMAL ANALIYSES}

\section{TABLE 1. TABLE OF SIGNIFICANT DIMENSIONS OF THERMAL INTEREST}

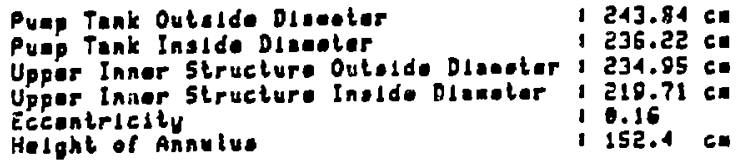

\section{MODELIING OF CONVECTION PATTERN}

A buoyancy driven cellular conrection flow pattern is introduced in the annulus region between the upper inner structure and the pump tank. The following assumptions are used regarding the flow associated with the cellular convection:

1. The lowest wave number convection mode is assumed for both the vertical and circumferential directions for high pressures. In other words, there are only two cells in the annulus. For the
The finite element thermal model consists of the 246 isoparametric thermal solid elements (STIF 70 in Reference 2.), whose materials are either stainless steel or steel shot. The main assumption in the model is an adiabatic wall boundary condition in the shaded region of Figure 1 . In addition to the solid elements, 39 radiation link elements (STIF 3I), 158 convection link elements (STIF 34), and 72 transient thermal-flow pipe elements (STIF 66) are used for the computer model.

Natural convection from horizontal surfaces or vertical cylinders is assumed as:

$$
\mathrm{Nu}=0.13 \text { (Gr Pr) } 1 / 3
$$

This relation is used for both the air and argon sides.

Radiation between sodium and the wall is determined by assuming all surfaces were connected to an imaginary node in the center of the enclosure and have a shape factor of one between surface nodes and the center node. This center node thus represents an average, 
The final analysis is done through an iteration technique by assignina an apuropriate pump head in the flow loop and subsciutintly verifying its accuracy by calculating the static head differential based on the new ly determined temperature distribution.

CORRELATION OF EXPERIMENTAL DATA

In order to correlate the experimental data with the model, it is necessary to adjust the relation between the input pump head and the resulting static head-differential which are expected to be the same. In general, the data show that the resulting head-differential is about three times higher than the invut pump head at best correlation points. It can be attributed to the eccentricity or the annulus, entrance efjects of the annulus, and the deviation of the flow field from plane Poiseuille flow. These effects can increase both the heat transfer coefficient and the Eriction factor.

Figure 2 shows the initial pump head versus the resulting static pump head differential for the outermost loop. The circles represent selected converged points assuming a linear relation between the pump head and the static head differential in the vertical flow column.

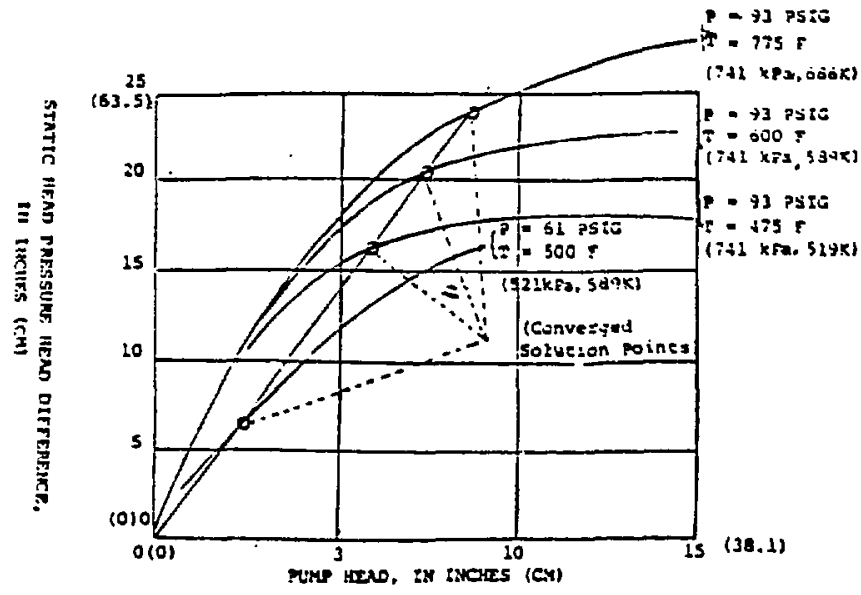

FIGURE 2. SELECTED COMUERGED SOLUTION POINTS BASED ON LINEAR HEAD RELATIOH

Figures 3,4 and 5 show the comparison of the results with the test data. The location of the thermocouples used in the test are shown in Figure 1 .

$93 \mathrm{psig}(741 \mathrm{kPa})$ test data are compared in Figures $3 a, 3 b$ and $3 c$. The agreement is excellent. Deviation of the results from the test data appear near the top of the falling column at $775^{\circ} \mathrm{F}(686 \mathrm{~K})$ sodium temperature. At this location, the temperature of the argon reaches a minimum which is well below the sublimation point of the sodium vapor.

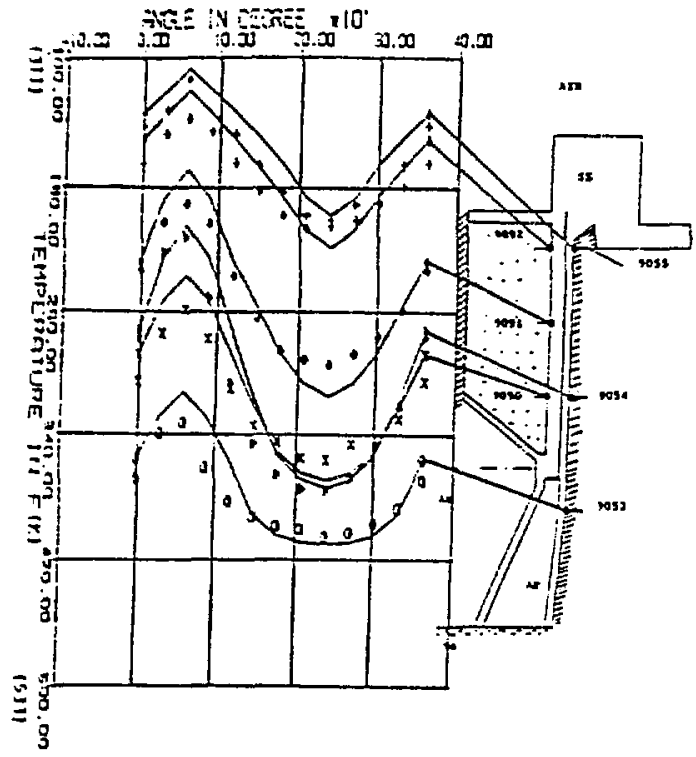

FTGURE Ja. COMPARISION OF TEST DATA UITH MODEL PREDICTION (SOLID LINE) AT 93 PSIG ( $741 \mathrm{KPa}$ ) ARGON PRESSURE SODIUM TEMPERATURE: $475 \mathrm{~F}$ (519 $\mathrm{X}$ )

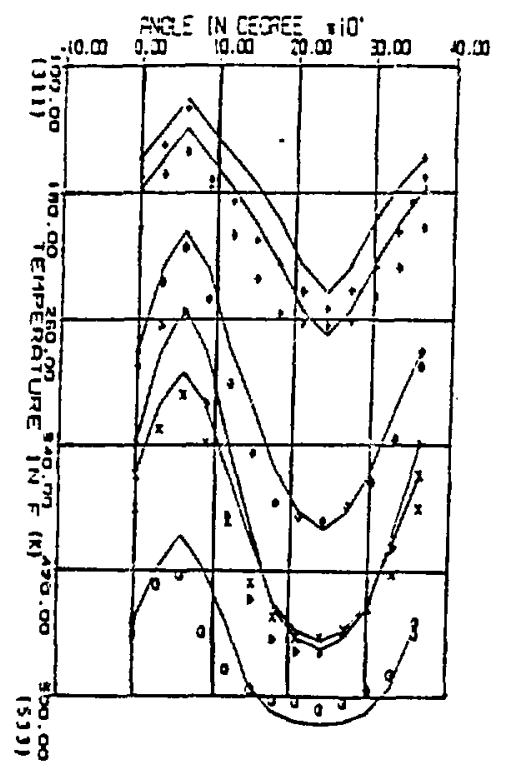

FIGURE 3b. COMPARISION OF TEST DATA UITH MODEL PREDICTION (SOLID LINE) AT 93 PSIG (741 KPA) ARGON PRESSURE SODIUM TEITPERATURE! $600 F$ (58S X) 


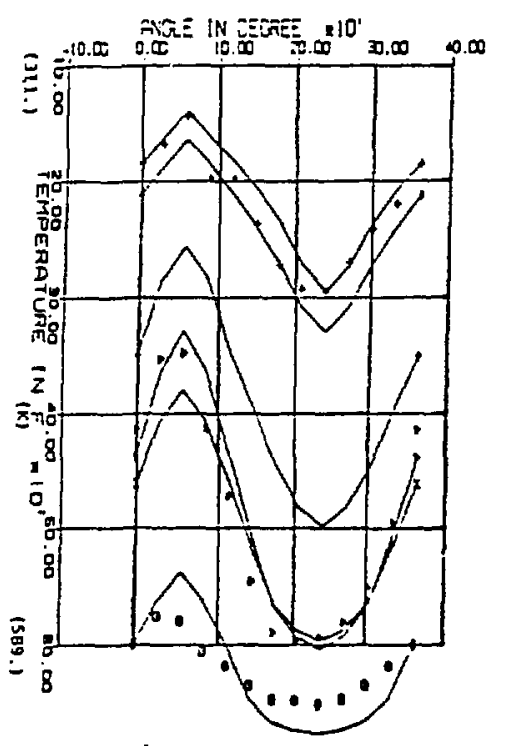

FIGURE 3C. COMPARISIOM OF TEST DATA UITH MODEL PREDICTION (SOLID LINE) AT 93 PSIG (741 KPa) ARGON PRESSURE SODIUN TEMPERATURE: 775 F (G86 K)

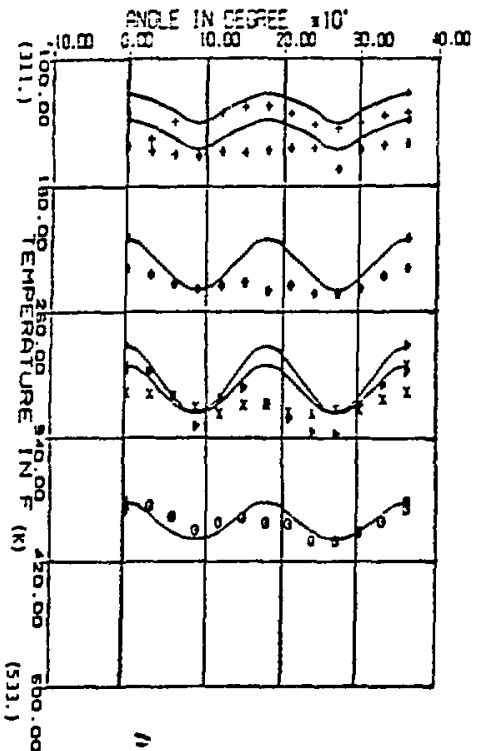

FIGURE Sa. COMPARISIOM OF TEST DATA WITH MODEL PREDICTION (SOLID LINE) AT 3 PSIG (IZZ KPa) ARGON PRESSURE SODIUT TEMPERATLRE: $475 \mathrm{~F}(519 \mathrm{~K}$ )

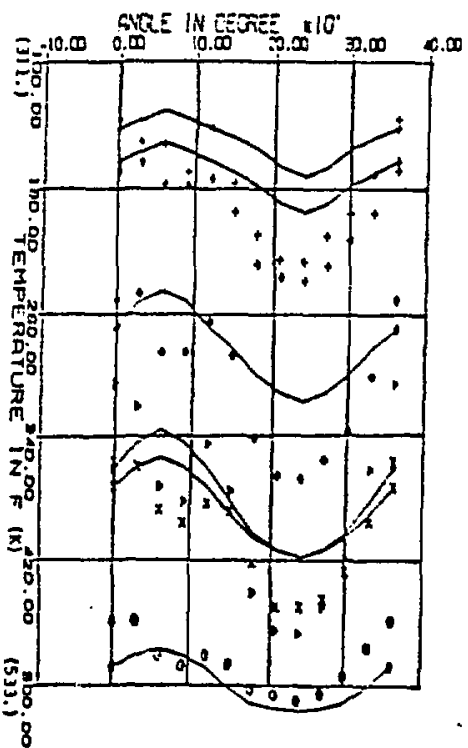

FIGLRE 4. COMPARISION OF TEST OATA WITH MODEL FREDICTION (SOLID LINE) AT 61 PSIG (521 KPg) ARGON PRESSURE SODIUM TEMPERATURE! B00 F $(589 \mathrm{~K})$

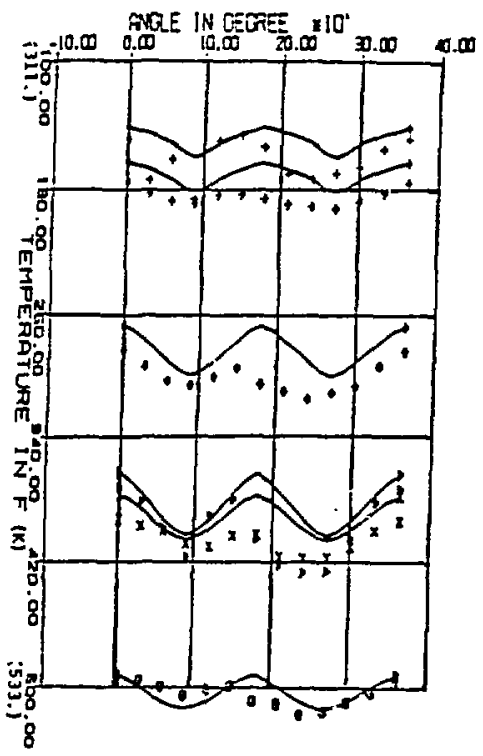

FIGURE 5b. COMPARISION OF TEST DATA WITH MODEL PREDICTION (SOLID LINE) AT 3 PSIG (122 $X P Q)$ ARGON PRESSURE SODIUM TEMPERATURE: $600 \mathrm{~F}$ (589 K) 


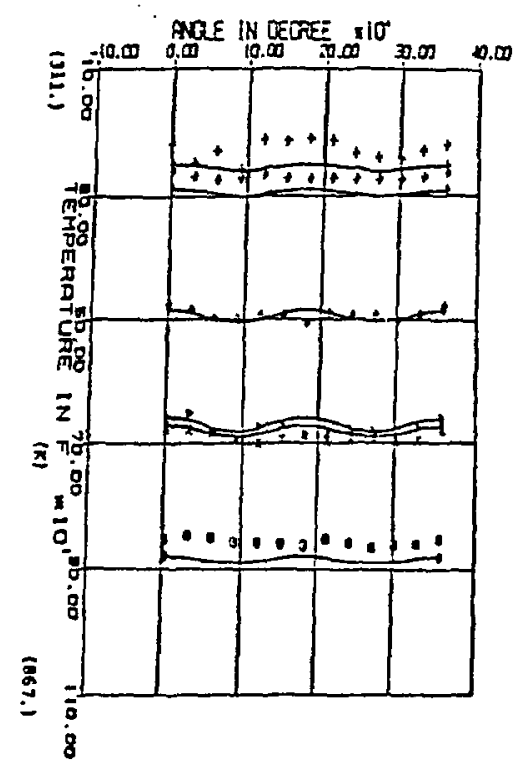

FIGURE 5C. COMPARISION OF TEST DATA WITH MODEL PREDICTION (SOLID LINE) AT 3 PSIG (12: KP ) ARCON PRESSURE SODIUT TEMPERATURES 1800 F (811 K)

This suggests a possible exie' ice of sodium frost which may influence + ilular convection flow field.

Figure 4 shows the same co. -ison at 61 psig (521 kPa) pressure. As -. pressure decreases, the effects of convection weaken significantly. However, test data indicate that the model overpredicts the effect of pressure reduccion. = This may be a result of using the same linear relation between calculated head and assumed pump head for both high and low pressures. When the pressure is reduced to 3 psig (122 kPa), the results show almost no effect of cellular convection. Therefore, to improve the correlation, a possible maximum pump head (a static head differential based on the coldest and hottest temperature in the loopl is used instead of the pump head obtained from the above relation, along with a four cell convection pattern. The results are compared in Figures $5 a, 5 b$, and $5 c$ and stiow a good agreement.

The discrepancies in predicted values due to the convergence criteria in the lower pressure tests can be i.tributed to the external air side convection between the pump tank and the insulation. Test data also show almost no change of temperature distribution betwesn pressures of $3 \mathrm{psig}(122 \mathrm{kPa})$ and near vacuum.

It is suggested by Wooding (4) that a square cell (four cell mode in our present configuration) is most probable for adiabatic walls. For infinitely conducting walls, which can be applicable to our condition,
Edwards (1) shows that the number of cells may be higher than exist with an adiabatic wall. The difference in the number of celis between the stibility theory and test results may also be due to eccentricity erfects.

\section{CONCIUSIONS}

A three-dimensional finite-element analysis of the cellular convection phenomenon in the Clinch River Breeder Reactor Prototype Pump was performed using the computer code ANSIS (2).

Steady-state thermal data were obtained for several test conditions for argon gas pressures up to $93 \mathrm{psig}$ ( $741 \mathrm{kPa}$ ) and sodium operating temperatures to $1000^{\circ} \mathrm{F}$ (811 K). Test temperature distributions on the pump tank and inner structure were correlated. With numerical results and excellent agreement was obtained.

This model has been used as the basis for a design modification which is being implemented in the prototype pump, and which will be tested to confirm resolution of the ooserved temperature asymmetry.

\section{ACKNOWLEOGENENT}

Grateful acknowledgement is made to Dr. K. Huber, Mr. K. Lemmon, Mr. $M$. Hugins, Mr. M. Cook, Mr. C. Reimers, and

Mr. F. Costanzo of Byron Jackson Energy Systems Development Center and Mr. J. Grimaldi and Mr. L. Manners of General Electric Company Advanced Reactor Systems Department for their support of this program.

\section{REFERENCES}

1. Edwards, D. R., "Suporession of Cellular Convection by Lateral Walls," Journal of Heat Transfer. Trans. ASME, Series $C$, Vol. 91 (2), Feb. 1969, PP. 145-150.

2. Swanson Analysis systems, Inc., ANSYS Engineering Analys is Syster; Swanson Analysis sustems Inc., Elizabeth, Pa. (1976).

3. Edwards, D. K., Denny, V. E. and Mills, A. F.. Transfer Processes, Holt, Rinehard, and אinston, Inc. March 1977.

4. Wooding, R. A., "Instability of a Viscous Liquid of Variable Density in a Vertical Hele-Shaw Cell" Journal ot Fluid Mechanics, Vol.. 7, 1960, pp. 501-515. 


\section{DISCLAIMER}

This report was prepared as an account of work sponsored by an agency of the United States Government. Neither the United States Government nor any agency thereof, nor any of their employees, makes any warranty, express or implied, or assumes any legal liability or responsibility for the accuracy, completeness, or usefulness of any information, apparatus, product, or process disclosed, or represents that its use would not infringe privately owned rights. Reference herein to any specific commercial product, process, or service by trade name, trademark, manufacturer, or otherwise does not necessarily constitute or imply its endorsement, recommendation, or favoring by the United States Government or any agency thereof. The views and opinions of authors expressed herein do not necessarily state or reflect those of the United States Government or any agency thereof. 